\title{
コンクリートブロックを用いた粗石式魚道の 水理および遡上特性 \\ HYDRAULIC AND FISH ASCENDING CHARACTERISTICS OF CONCREAT BLOCK STREAM TYPE FISHWAY
}

\author{
桜井 力 1 -柏井条介 2 - 佐々木國隆 3 - 岡㠃克美 4 - 進藤邦雄 5 - 岡本俊策 6 \\ Tsutomu SAKURAI, Josuke KASHIWAI, Kunitaka SASAKI, Katsumi OKAZAKI, \\ Kunio SHINDOH, Syunsaku OKAMOTO \\ 1 正会員 工修 建設省土木研究所ダム部水工水資源研究室 主任研究員（テ305-0804 つくば市旭 1) \\ 2 正会員 建設省士木研究所ダム部水工水資源研究室 室長（テ305-0804 つくば市旭 1） \\ 3 正会員 株式会社ホクエツ設計部 部長（T984-0002 仙台市若林区御町東 1-1-52）。 \\ 4 株式会社テトラ環境事業本部環境エンジニアリング部 課長（テ160-8350 東京都新宿区西新宿6-3-1） \\ 5 正会員＼cjkstart共和コンクリート工業株式会社技術研究所＼cjkstart所長（０61-1405＼cjkstart北海道恵庭市戸磯385-36） \\ 6技研興業株式会社＼cjkstart技術一部 次長（广150-0031 東京都渋谷区桜丘町13-10）
}

\begin{abstract}
From the viewpoint of preservation of the ecosystem of rivers, expectations are on the rise for various fishways for fish migration. Stream type fishways with cobble stones and boulders as roughness elements create a good natural landscape. These type of fishways offer a wide variety of flows with different depths and appear as murmuring little streams or as high-speed rapids. This research aims to develop a new type of fishway which can reduce the costs and time and look like as a natural stream. We analyzed the hydraulic characteristics of a fishway built with concrete blocks that was developed with the earlier mentioned objectives using hydraulic testing. Based on it, a design method was proposed. Further, we conducted ascending tests for many kinds of fish and the results confirmed that this type of fishway is well used by all the tested fish under various flow conditions
\end{abstract}

Key Words : stream type fishway, hydraulic test, ascending test, concrete block, roughnes

\section{1. はじめに}

河川の生態系保全の観点から多様な魚種の遡上可 能な魚道への期待が高まっている。粗石魚道は粗石 を粗度として用いたもので、横断方向にも勾配を付 けることによって多様な水深と流速場や、せせらぎ 的な流れも形成できる景観上も優れた魚道である。

1) しかし、現在用いられている粗石魚道は、自然石 を用いてその不定型さや礫間の隙間などを利用する ものであり高コストなものである。また、流れは複 雑であり種々の魚道条件 (幅、縦断勾配、水深など) の設計手法については未だ確立されていない。 本研究は、この粗石魚道をコンクリートブロック 化し、コスト低減および工期の縮減等を図ったもの である(以下ブロック式魚道と呼ぶ)。実物大モデル による水理実験を行い、魚道の形成する流速場を測 定・解析し、現地の地形や流量条件に合わせた粗度 形状や縦横断勾配等の設計手法の提案を試みた。

また、魚道の代表的な対象魚としてアユを、遊泳 能力の小さい底生魚としてヨシノボリおよびヌマチ チブを用いて、種々の粗度配置および流量条件下に
おける遡上状況を確認した。

\section{2. 粗度配置の検討}

ブロック式魚道の検討に先立って、円筒を水路に 規則的に配置した魚道についての基礎的な検討を行 い、ブロック式魚道を設計する際の粗度規模および 配置と得られる流速場の関係を求めた。

（1）実験方法

実験は幅 $50 \mathrm{~cm}$ 長さ $15 \mathrm{~m}$ 勾配 $1 / 20$ の水路に表 -1 に示す円筒による粗度を設置して行った。円筒の配 置については $1 \sim 3$ 列とし、流下方向の間隔は $20 \mathrm{~cm}$ 、 とした。計測は、水深、流速および流量について、 それぞれポイントゲージ、直径 $5 \mathrm{~mm}$ のプロペラ式流 速計および電磁流量計を用いて行った。

（2）実験結果

実験結果を整理するために、ここでは、流速と粗 度形状の関係式として以下のマニングの粗度係数 を用いるものとした。

$$
n=\left(R^{2 / 3} I^{1 / 2}\right) / v_{e}
$$


表-1 粗度形状と配置

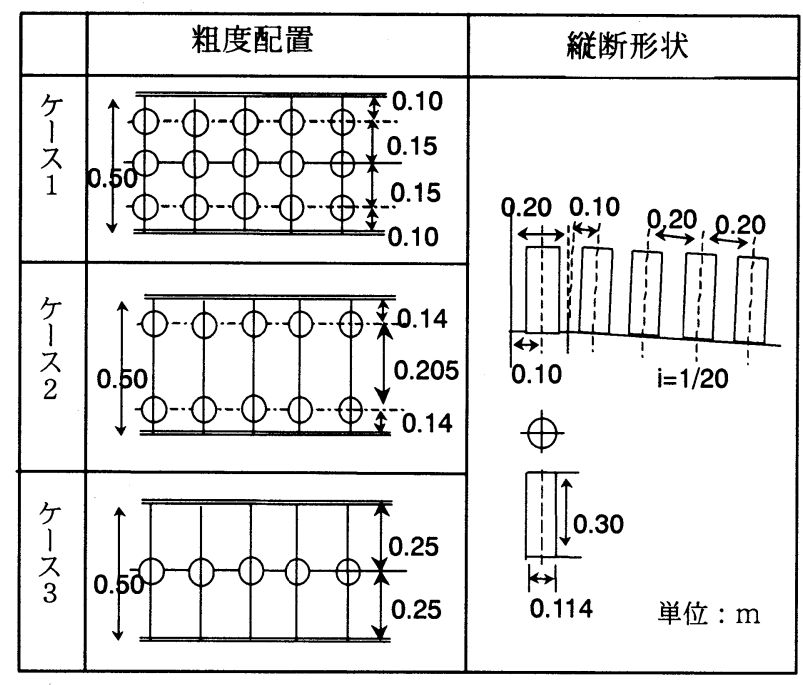

ここに、 $n$ :マニングの粗度係数, $R$ : 径深, ${ }^{v_{e}}$ : 断面平均流速 なお、径深 $R$ および断面平均流速 $V_{e}$ は横断方向に粗 度のない断面の值を用いている。

水路の抵抗は、流下面積に対する粗度の占める面 積の影響が大きいと考えられるので、次の遮蔽率 $\alpha$ を用い、粗度係数 $n$ との関係を調べた。

$$
\begin{aligned}
& \alpha=A_{r} / A_{t} \\
& \text { ここに、 } A_{r}: \text { 粗度の流下方向の投影面積, }
\end{aligned}
$$$$
A_{t}: \text { 粗度を含む水路全体の断面積 }
$$

図-1 に粗度係数と遮蔽率の関係を示した。粗度 は遮蔽率の増加とともに大きくなり、その関係はほ ぼ以下の近似式で表すことができる。

$$
n=0.0332(1-\alpha)^{-1.7}
$$

なお、上式は流下方向の粗度間距離を $20 \mathrm{~cm}$ すな わち円筒直径の 2 倍とした場合の関係式である。し たがって、適用に際してはこの条件を考慮しておく 必要があるが、同時に実施した実験結果によれば径 の $1.5 〜 2.5$ 倍の範囲であれば粗度は土5\%程度しか 変化しておらず、実用上は同様の取り扱いが可能で ある。2)

\section{(3) 粗度配置}

図－2にブロック式魚道断面の基本形状を示し た。流速は水深が大きいほど大きくなる傾向があり、 流速低減の方法としては、粗度を配置するとともに、 水深を小さくする方法がある。アユカケやヨシノボ リ等の遊泳力の小さい魚種では魚体自体もそれほ ど大きくないため大きな水深を要求しない。また、 前述の検討から考えても数十 $\mathrm{cm} / \mathrm{s}$ という小さい流 速を水深の大きな領域で確保するのは、遮蔽率が非 常に大きくなり、効率的ではない。これらを考慮し、 水路の横断方向に水深を変化させる水路を用いる こととした（図一 2 ）。水路幅は比較的実施例の多

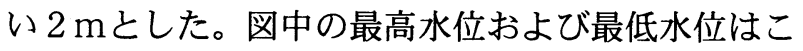
の魚道の利用水深範囲の上下限を示したものであ る。最低水位はサクラマスなど比較的魚体の大きな 魚種を考慮し、最高水位は流量変化および横断方向

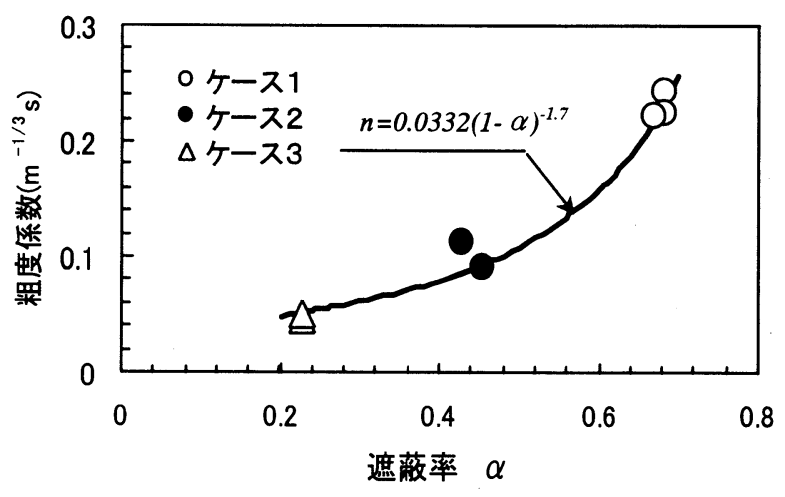

図-1 遮蔽率と粗度の関係

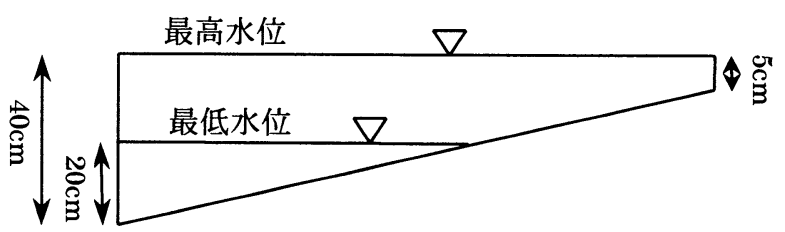

図-2 ブロック式魚道基本形状（横断面）

の勾配を考慮して設定したものである。横断方向の 勾配は、幅方向に緩やかな流速変化となり、多様な 流速場が得られるように $1 / 6$ 程度の勾配とした。

設計流速としては、最高水位において最深部で 1 $\mathrm{m} / \mathrm{s}$ 、最浅部で $0.3 \mathrm{~m} / \mathrm{s}$ として連続的な流速変化を想 定した。最高水位を設計の対象としたのは、水位が 低下すれば必然的に流速は小さくなり、魚道として は良好な状態に移行すると考えられるためである。 $1 \mathrm{~m} / \mathrm{s}$ の流速は大型のアユおよび大型魚の巡行速度 を想定したものである。また、 $0.3 \mathrm{~m} / \mathrm{s}$ の流速は別 途実施している実験結果 ${ }^{1)}$ により、体長 $2 \sim 4 \mathrm{~cm}$ の
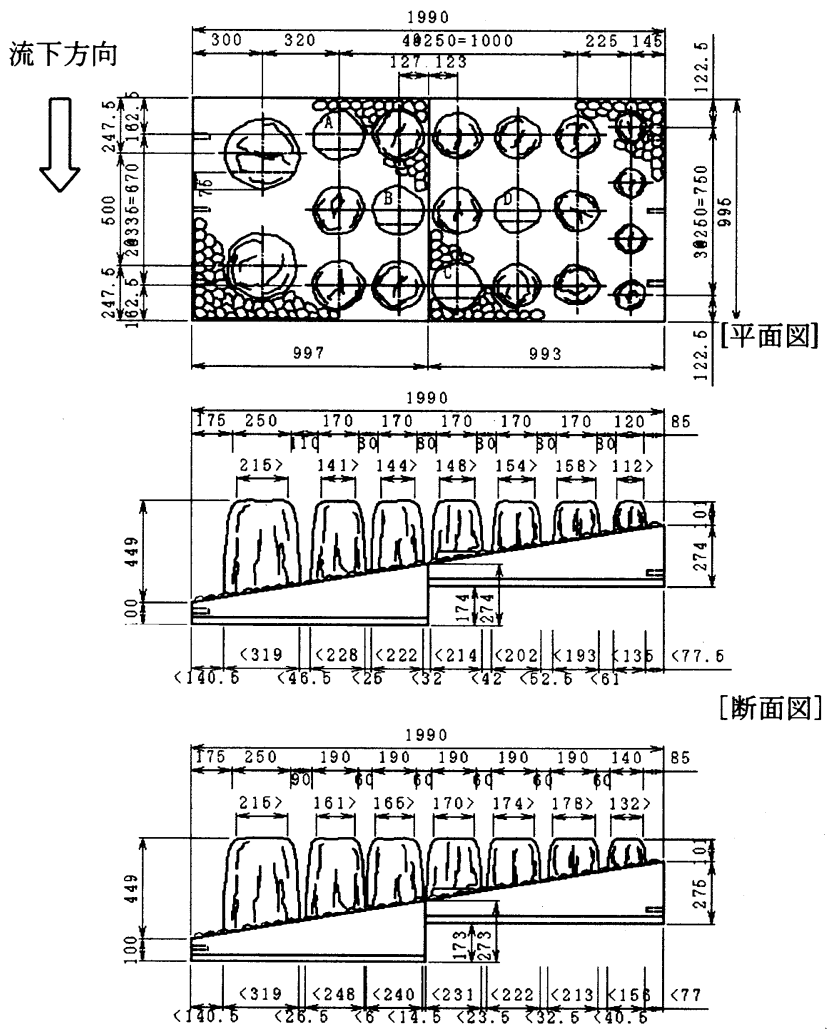

注）断面は上段が $1 / 8 \sim 1 / 12$ 勾配、下段が $1 / 5$ 勾配 図ー3 実験に用いたブロック式魚道 
カジカやアユカケが流速 $0.4 \mathrm{~m} / \mathrm{s}$ 以下の流速場にお いて遡上していることを考慮したものである。

施工上の都合や魚が遡上できるようにある程度 粗度間の幅を確保する必要から、円筒はある程度以 上の大きさにする必要があり、粗度係数を連続的に 変化させることはできない。したがって、実際の設 計に際しては、まず、形状・配置を設定し、これか ら遮蔽率、粗度係数を求め、流速を計算して想定し た値となっているかを検証することになり、多少の 繰り返し計算による形状設定が必要となる。

このようにして求めた粗度形状・配置の基本単位 をもとに施工性等も考慮して設計したブロック式 魚道を図ー 3 に示した。円筒には高さ方向に若干の 筋状の凹凸を設けるとともに、脱型を考慮して上部 をやや細くしている。また、底部にも底生魚の休款 所となるように石状の凹凸を設けた。コンクリート ブロックはこの横断方向 $2 \mathrm{~m} \times$ 流下方向 $1 \mathrm{~m}$ を基本単 位として、これを流下方向に並べていくこととなる。 また、施工上の都合からこの基本単位を 2 つのブロ ックで製作している。なお、得られる流速の差がわ ずかであることから勾配 1/8～1/12 は同一形状とし た。この形状において得られる粗度および流速の計 算值を図ー 4 に示した。図中の粗度および流速は中 央に円柱を 1 つ含むようにブロック分けした各断 面の值を示したものである（以下断面流速と呼ぶ。）。 最深部が想定した流速よりも大きくなっているの は、大型魚のために粗度の間隔をやや大きく設定し たためであるが、特に支障が生じる程大きな流速と はなっていない。

また、1/5 の勾配はこれまでの実績と比較してか なり急勾配となっており、これが実用化可能であれ ば、魚道設計の自由度をかなり增すことができるも のと考えられる。なお、ここで示した魚道形状は、 基本的な粗度配置であるが、現場の種々の設計条件 に対しても同様の設計手法で形状を決めることが可 能である。

\section{3. ブロック式魚道の水理特性}

\section{（1）実験方法}

前述の 2 形状の魚道を実際にコンクリートブロッ クとして試作し、水理実験を行った。実験を行った 流量条件等を表一 2 に示した。なお、流量 250 l/s

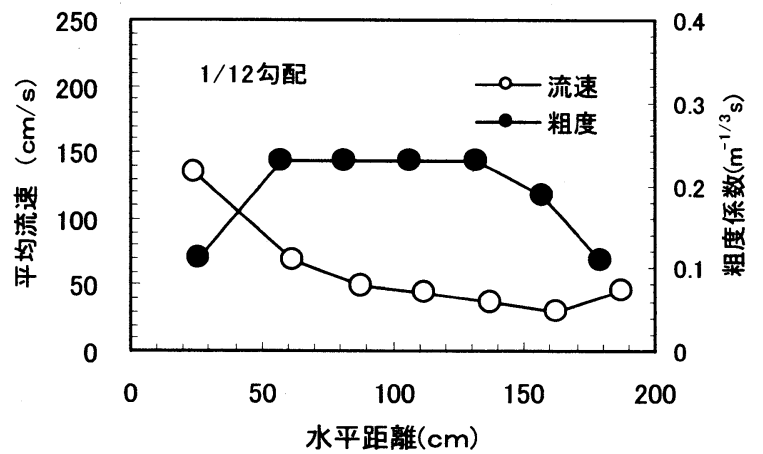

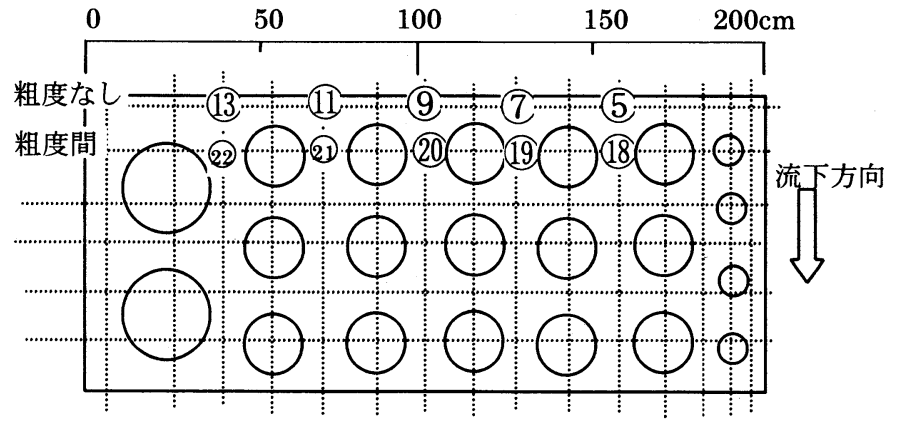

注）測定は破線で示した測線の各交点で行った。本文図中で引 用した測線および測点のみ名称を記入した。 図ー5 測線および測点

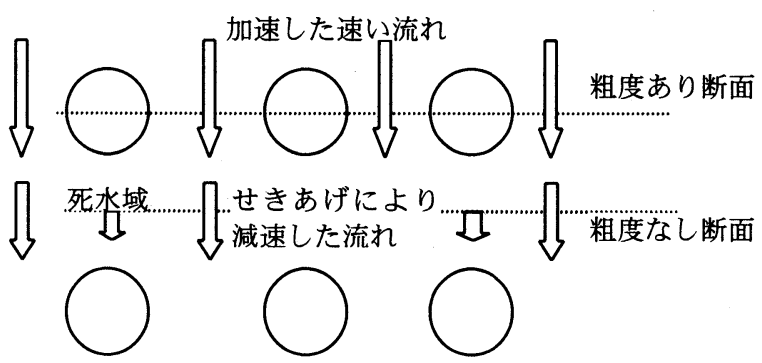

図－６フプック内の流況

が最高水位に $50 \ell / \mathrm{s}$ が最低水位に対応している。各

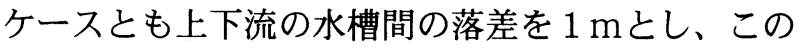
間にコンクリートブロックを敷き並べた。ただし、 上流 1 ブロック分（1 m区間）は整流区間として水 平にブロックを設置した。測定機器は前述の実験と 同様である。また、測定を行った測点および測線を 図ー6に示した。

表 -2 ブロック式魚道の実験条件

\begin{tabular}{|c|c|c|}
\hline & 勾配 & 流量 $(\ell / s)$ \\
\hline 形状1 & $1 / 8,1 / 12$ & $50,100,150,200,250,300$ \\
\cline { 1 - 1 } 形状2 & $1 / 5$ & \\
\hline
\end{tabular}

（2）流速場の特性

流下方向の水深は、上流の水平部を含む 2 ブロッ クおよび下流の水槽水位の影響を受けているブロッ クを除いて各ブロックの同一箇所はほほ同じ水深と なっていた。したがって、流れは等流と見なすこと ができ、また、ブロック単位でほぼ同一の流況が繰

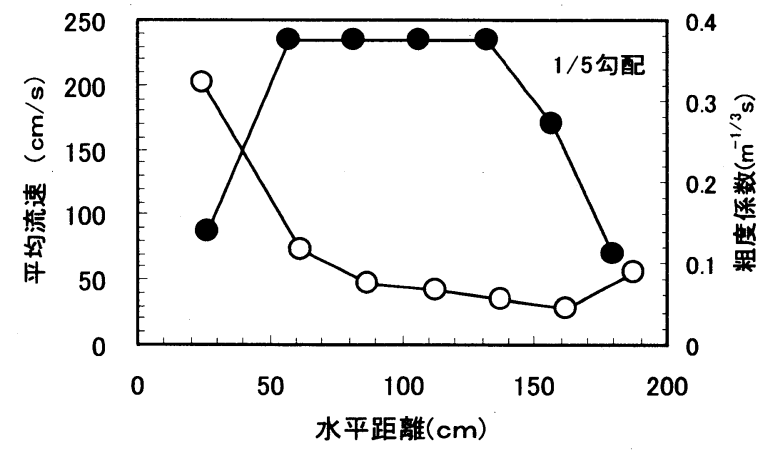

図-4 粗度係数および流速の計算値(横断面) 

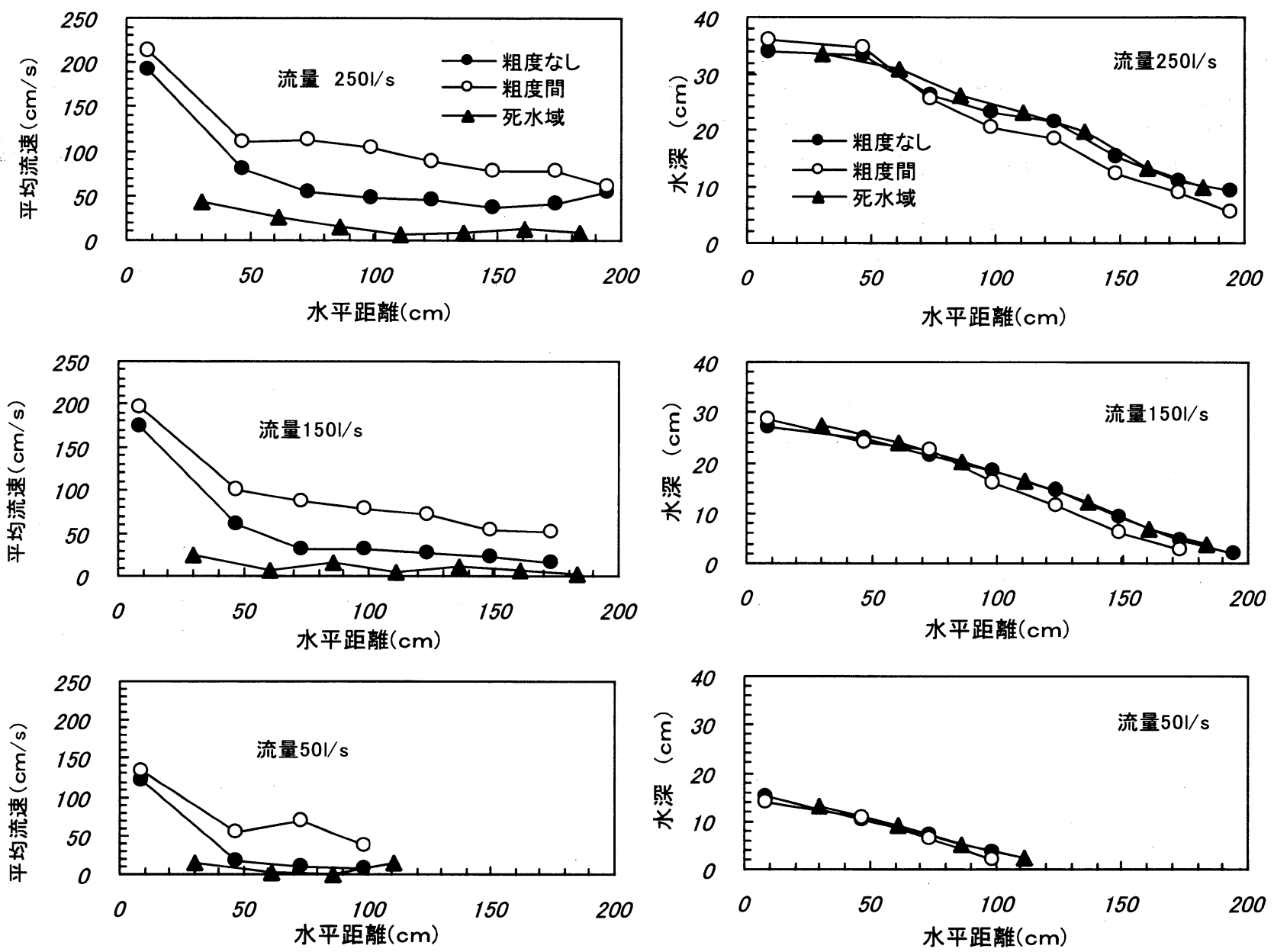

図-7 ブロック式魚道の平均流速分布(横断面)
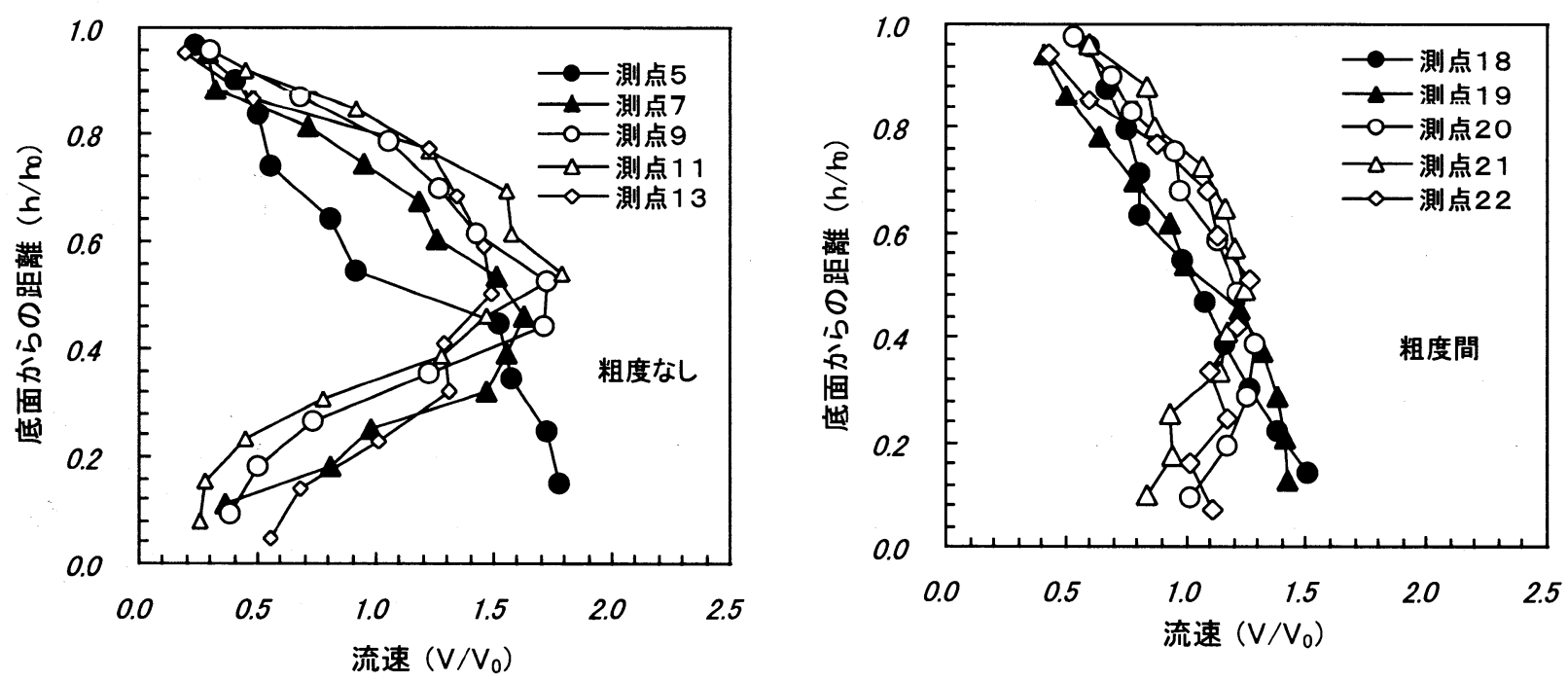

図-9 繸断方向に粗度のない測線における深さ方向の流速分布(勾配1／12、流量 $250 \ell / \mathrm{s}$ )

り返されていると考えられる。

各ブロック内の流れは図一 6 に示すように大きく 3 つのパターンに区分される。すなわち、横断方向 に粗度のない断面では粗度背後の死水域と流速の大 きな粗度のない領域の繰り返しとなる。一方、流下 方向に粗度のない測線でみると、粗度のない断面で 流れがせき上げられることにより減速し、粗度があ る領域ではせきあげられた水位によって流れは加速
している。なお、以後簡単のため、流下方向に粗度 のない領域のうち横断方向に粗度のある領域を粗度 間、粗度のない領域を粗度なしと呼ぶ（図－5）。

図一 7,8は、形状 1 の勾配 1/12 のケースについ て横断面における深さ方向に平均した流速（以下平 均流速と呼ぶ。）と水深の変化を示したものである。 流速は最深部を除いてほぼ $1 \mathrm{~m} / \mathrm{s}$ 以下となっており 水深の変化に応じて連続的に緩やかに変化している。 
水深も連続的に変化しており、水位は横断方向にほ ぼ一定となっている。また、粗度なしと粗度間を比 較すると、水深の深い領域では大きな減速は見られ ないものの他の領域では粗度なし断面では粗度間の $5 \sim 8$ 割程度の減速が生じており、その割合は流量 が小さいほど大きい。水深の変化はわずかであり数 $\mathrm{cm}$ の上昇となっている。なお、他形状もほぼ同様の 傾向を示している。

勾配 $1 / 12$ 、流量 $250 \ell / \mathrm{s}$ 時の水深方向の流速変化 を粗度間、粗度ありに分けて図ー9に示した。なお、 流速は平均流速で、底からの距離は水深でそれぞれ 無次元化している。図によれば粗度間、粗度なしと も水深に依らずほぼ一定の分布形状となっているこ とがわかる。粗度間では底部に行くに従い徐々に流 速が大きくなるが、その変化はわずかである。一方、 粗度なしの領域ではやや流速の変化は大きくなり、 表層部と底部の流速が遅く、中間部で最も流速が大 きくなる。こうした傾向および流速の変動幅は、流 量、形状および勾配によらずほぼ一定であった。

(3) 設計流速の検証

図ー10 に粗度なしの測線における断面平均流速 （計算值と同様、円柱単位での断面平均流速）の実 測値と計算値を比較して示した。底面等に設計上考 慮しなかった凹凸を設けたため、各形状とも計算値 よりやや小さい值となっているが、流速はほぼ想定 した範囲内で連続的に変化しており、提案した設計 手法の有効性が確認された。

\section{4.ブロック式魚道の遡上特性}

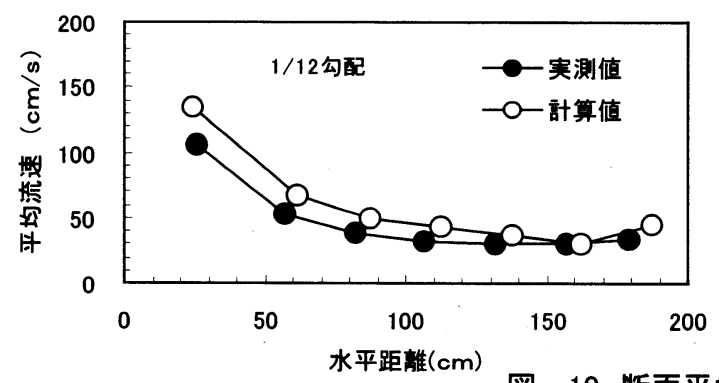

図-10 断面平均流速の実測値之計算値の比較
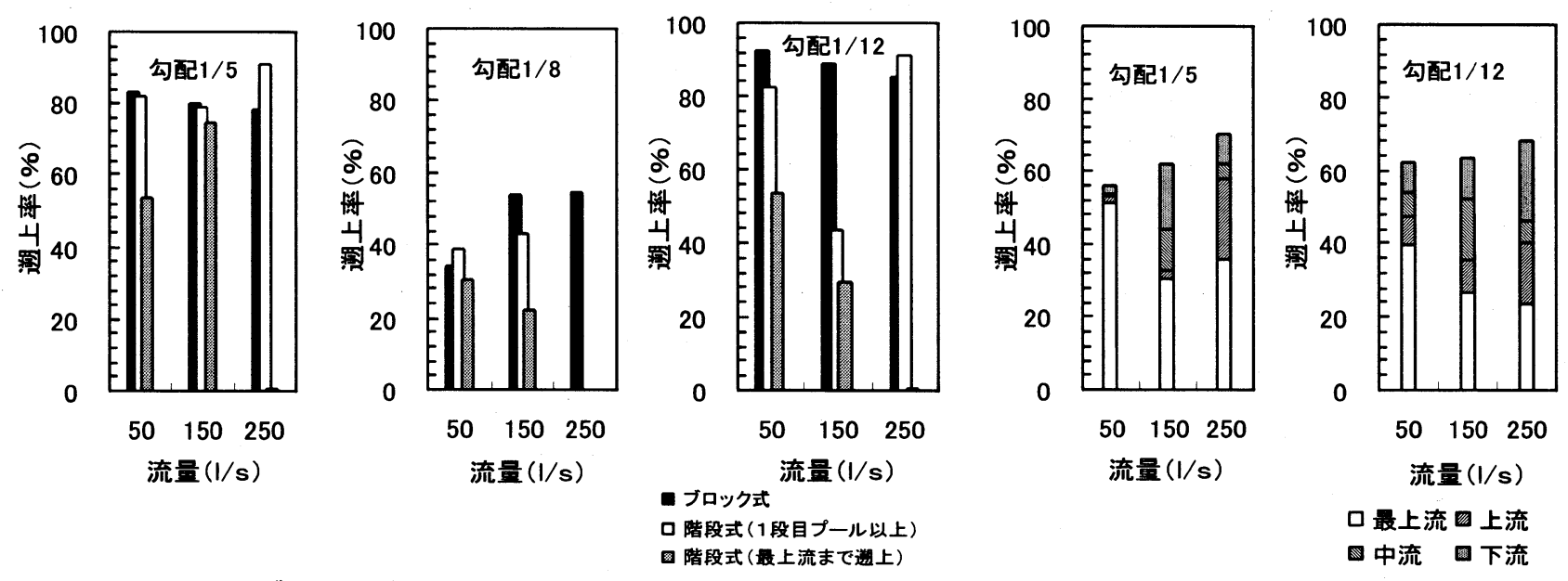

図ー11 ブロック式魚道と階段式魚道の遡上率(アユ)
（1）実験方法

実験は水理実験に用いた施設で行った。流量は、 基本形状の最高水位に当たる $250 \ell / \mathrm{s}$ 、最低水位に当 たる $50 \ell / \mathrm{s}$ およびこれらの中間の 150 l/s とした。 対象魚は、アユおよび底生魚とした。アユは養殖魚 であり、底生魚は近傍の河川より捕獲したもので、 ヌマチチブとヨシノボリがほぼ同数混在している。 アユの実験時間は筆者らが行ったこれまでの遡上実 験における検討結果 ${ }^{3)}$ から、遡上活動が盛んになる 照度変化の激しい日出、日没を含む夕方 4 時から翌 朝の 9 時までとした。底生魚については遡上に時間 を要するため ${ }^{1)}$ 朝 10 時から 3 日目の朝 10 時までの 3 日間とし、 2 日目に一度通水を中断して遡上魚を 捕獲した。ともに実験開始 1 時間前に魚を下流プー ルへ投入し落ち着かせた後に実験を開始した。

実験尾数は実験の再現性、統計処理の有意性を保 つために 100 尾程度とした。また、遡上実験は、実 験時期や実験魚の体調等により遡上意欲が異なって くるため絶対的な評価が難しい。そこで、アユの遡 上実験時には、囘時に階段式魚道 (勾配 $1 / 25$, 階段 数 6) においても実験を行い、遡上率を比較した。

なお、実験場所の制約から実験時期および対象魚 はケースによって異なっており、勾配 1/8 のブロッ ク式魚道は 5 月にアユを、勾配 $1 / 12$ および $1 / 5$ の魚 道は 6 月にアユを 7 月に底生魚の実験を行っている。 (2) 実験結果

各形状、流量におけるブロック式魚道におけるアユ の遡上率を同日に実施した階段式魚道における遡上 率とともに図ー11 に示した。なお、階段式魚道では、 一部かなりのアユが途中プールに留まっているケー スが見られたのでプール 1 段以上遡上した場合も併

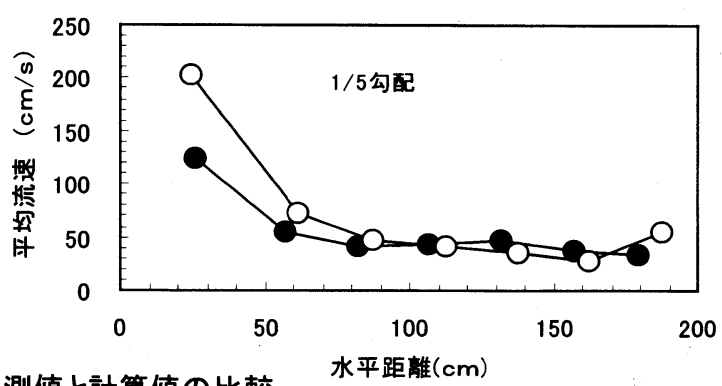



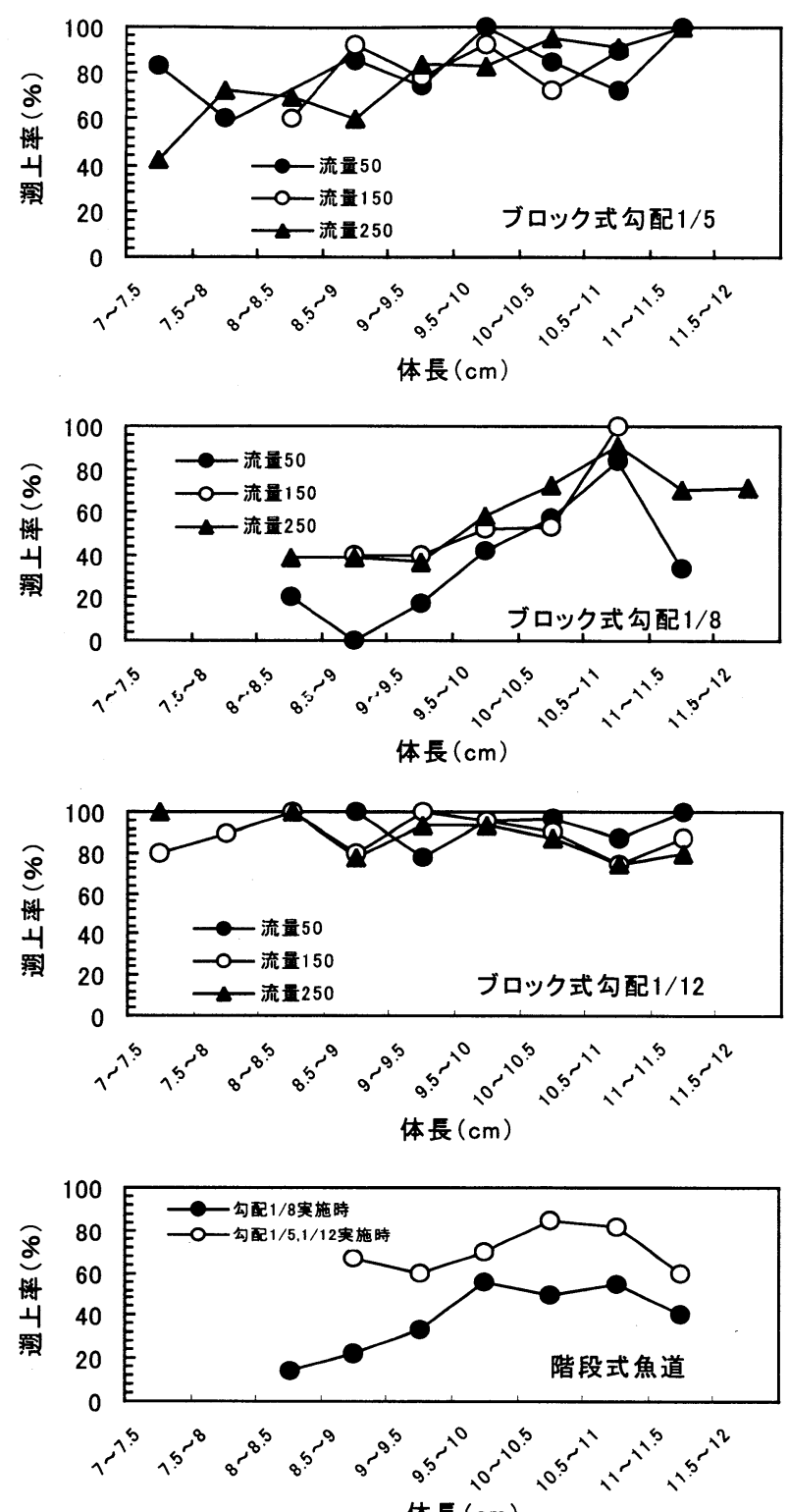

図-13 ブロック式魚道と階段式魚道の体長別遡上率(アユ)

記した。勾配 $1 / 5$ および勾配 1/12 のブロック式魚道 は流量にかかわらずほぼ $80 \%$ 以上と階段式とほぼ 同程度の遡上率を示している。勾配 1/8 のブロック 式魚道はやや遡上率が低く $50 \%$ 程度に留まってい るが、同日に行った階段式魚道も同様に遡上率が低 くなっており、実施時期が 5 月とやや早かったこと が原因と考えられる。流速も他勾配の魚道と同様適 切に制御されていること、流量の小さいすなわち流 速の小さい場合に遡上率が低下していることからも 遡上意欲が 6 月の実験時に比較して低かったと推測 される。なお、50\%の遡上率はこれまでの遡上実験 結果と比較して決して低い率ではなく、実用上特に 問題はない值と判断される。図ー13に、アユの体長 別遡上率を示した。勾配 1/8 を除いてほぼ体長によ らず一定の遡上率を示している。これは、遡上意欲 のある魚体であれば体長にかかわらず遡上可能であ ったことを示していると考えられる。勾配 1/8 のブ ロック式魚道は、特に流量の小さい、すなわち全体 としての遡上率が低かった場合に、より小さい体長
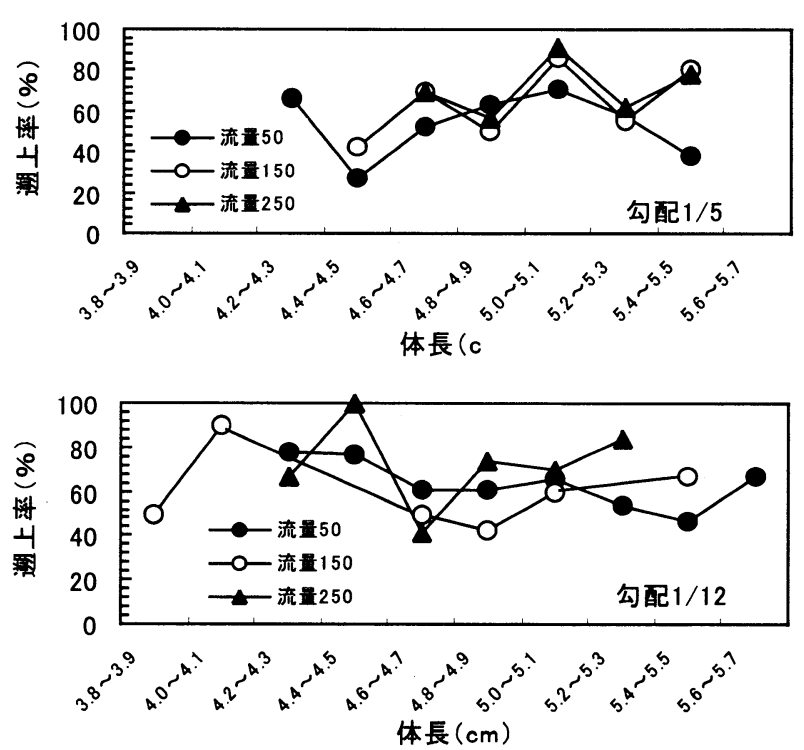

図ー14 ブロック式魚道の体長別遡上率(ヨシノボリ)

の魚体の遡上率が低い傾向を示している。図-13に 階段式魚道の体長別遡上率を併記したが、同様の傾 向が同時期の階段式魚道にも現れており、遡上率の 低下は流速等の水理的要因ではないと考えられる。

図-12 に底生魚の遡上率を示した。勾配 1/5、1/12 ともにほぼ $60 \%$ 以上の遡上率を示している。図-14 は底生魚の体長別遡上率を示したものであるが、ア ユ同様体長によらず一定の遡上率を示している。

なお、遡上経路については観察が難しく、十分な 検証が行えなかった。

\section{5. 結論}

本研究ではコンクリートブロックを用いた粗石式 魚道の開発を行い、その水理特性および遡上特性を 把握し、設計手法を提案した。これらの検討結果を まとめると以下のとおりである。

1) 本魚道は、多様な流速場を形成することができる。

2)本魚道は、勾配を $1 / 5$ と大きく採ることが可能で あり、設計の自由度が高い魚道である。

3) 本魚道は、多様な魚種が遡上可能である。

4) 本研究で提案した手法により、実用上十分な精度 で必要とされる流速場を有した魚道を設計できる。

今後は現地実験等により実用化を図っていくとと もに、ゲートへ直接設置すること等を念頭において さらなる急勾配の検討も進めていく予定である。

本研究にあたり、土木研究所水工水資源研究室 STA フェローシップ研究員 Dr. Kumar 氏に多大な御協 力を頂いた。ここに記して感謝の意を表します。

\section{参考文献}

1) 柏井条介, 村岡敬子:多様な魚種を対象とした魚道の遡 上実験, 土木技術資料, Vol. 38, No. 2, pp. 20-25, 1996

2) 野仲典理, G.S. Kumar, 柏井条介: 円筒を用いた水路式魚 道の遮蔽率と粗度係数の関係, 土木学会第 54 回年次学 術講演会講演概要集第 2 部, pp. 258-259, 1999

3) 田中和浩 : 階段式魚道におけるアユの遡上特性, 土木研 究所資料第 34 回土木研究所発表会論文集, 1996 